The difficulties of placing anthropology with this faculty or that are themselves evidence of the fundamental character of the science. A branch of instruction that may be claimed by different faculties, and, at the same time, not adequately represented in any, might justly claim title to a faculty of its own.

Anthropology has matured late; has been waiting for the contributions other sciences in the course of their development were bound to make to her; waiting till the prehistoric perspective came to supplement the historic, permitting man to take the same dispassionate view of self as of the rest of nature, till remote lands told their story of human variation and culture stages, and till the teachings of embryology and comparative anatomy were better understood. The development and succession of the sciences may be likened to the development and succession of the fauna of which man forms a part. As man is last and highest in the geological succession, so the science of man is the last and highest branch of human knowledge. It is to be hoped that the overflow from the sciences contributing to anthropology may be properly conserved and so distributed as to find its way more generally to the channels of university instruction. Whether the channel chosen be an existing faculty or a new and separate one is not so important as the stream it has to carry; and there is reason that to believe that stream is gaining in volume constantly.

After the foregoing article was in type, there came from his Excellency the Royal Prussian Kultusminister, in answer to my request of May 16th last for information, a manuscript statement handed in to him, September 27, 1899, by Professor Wilhelm Waldeyer entitled "Bericht über das anthropologishe Unterrichtswesen in Deutschland." From this the writer is able to supplement his own lists for Germany as follows :

Breslau, Dr. Partsch (Prof. ordin., Geography), 'Völkerkunde Europas'; Göttingen, Dr. von Bürger (Prof. tit., Zoology), 'Ursprung und Vorzeit des Menschen'; Heidelberg, Dr. H. Klaatsch (Prof. extraord., Anatomy), 'Anthropologie'; Kiel, Dr. Krümmel (Prof. ordin., Geography), 'Ausgewählte Kapitel der Anthropo-geographie'; K önigsberg, Dr. Bezzenberger (Prof. ordin., Comp. Philology), 'Urgeschichte Ostpreussens'; Strassburg, Dr. G. Schwalbe (Prof. ordin., Anatomy), 'Anthropologie'; Tübingen, Dr. von Sigwart (Prof. ordin., Philosophy), 'Philosophical Anthropology.'

This increases the number of German universities giving instruction in anthropology by seven, but does not augment the number of professorships.

Dr. W. H. L. Duckworth is the newly appointed University lecturer in physical anthropology at Cambridge.

George Grant MacCurdy.

YaLe UNIVERSity, New Haven.

\section{ECONOMICS, POLITICS AND FINANCE OF VOTING MACHINES.}

The writer, as a member, from its organization, of the New York State Commission to inspect and authorize voting machines for the use of the cities and towns of the state, and as Chairman for some years, to date, of the Finance Committee of the City Council of Ithaca, has had occasion to study the very novel and most ingenious construction of voting machines and to seek to ascertain their value in economics and politics, and as a matter of finance; and it is possible that economists and students of politics and of finance may find the deductions from this exceptionally fortunate experience both interesting and importantinteresting as a curious illustration of the 
inventive genius of our people and as an irruption of that genius into an unexpected line of work, important in its bearings upon good politics and on economics, through a better insurance of the expression of the real judgment and intent of the people, as given at the polls.

The 'voting machine' is an apparatus consisting of a very simple arrangement of a very simple form of mechanical counter, in groups, in such manner that, when the voter moves a handle or presses a button over a certain name, opposite the designation of a certain office, on the front of the machine, the act moves that individual counter one notch, and one is added to the reading on that particular count. It is also so arranged that, if the voter desires to vote a whole, ' $a$ straight' ticket, the pulling down of a handle, or the pressing of a button at the limit of the line of names of candidates, moves the counters of every individual candidate on that ticket and one motion counts a party-vote. Further, it is, in all approved voting machines, possible to vote any 'split ticket' and it is made a matter of fundamental construction that no voter shall be able to vote more than once for any candidate or for any party. In other words: the machine is constructed so that each voter shall, by the simple acts described, be able to vote, within the law, precisely as he may choose, while it is impossible for him to do anything which the law forbids. He has absolute freedom to do right; he cannot possibly do a legal wrong. The ingenuity and simplicity of these machines and the positive certainty of their operation as desired within legal limits make them, as a class, extraordinarily interesting studies in mechanism.

In New York, as in, now, quite 'a number of other states, there are provisions of law permitting and regulating the use of these machines and they have now had so extended and so extensive a trial that it is possible to speak positively of them as, where of approval construction, an entire and singular success. In New York, no voting machine can be employed until it has been fully inspected, carefully studied and unqualifiedly approved, by the Voting Machine Commission ; from whom a report must be secured, and filed in the office of the Secretary of State, to the effect that the machine is capable of registering six hundred voters in the election hours, accurately and efficiently, can be safely employed for that purpose, and that the Legislature of the State is justified in legalizing its use. Under these provisions of law, the cities of Buffalo, Rochester, Utica, Ithaca and other smaller places, have now used the machines in regular elections. In one or two places, older forms of machine, introduced before the commission for their inspection and endorsement was formed, have not proved satisfactory; but the later experiments have been entirely so, and Buffalo has 108, Rochester 73, and other places lesser numbers, all of which are reported to have proved a marvellous success.

One of these machines costs $\$ 500$, registers a maximum, under the law - there is no limit in construction-600 voters, at the rate of 5 to 15 seconds each voter, saves $\$ 16$ a year in cost of operating a precinct, $\$ 40$ to $\$ 50$ in election printing, and, by enabling a reduction to be made in the number of election precincts, saves about $\$ 200$ on each one abolished. In Ithaca, the reduction, if the law is followed precisely, will be not less than two nor more than four districts, out of ten; saving the city from twenty to forty per cent. net on the investment. The following were the conclusions reported by the Finance Committee to the City Council and the people of Ithaca :

\footnotetext{
"Summarizing our conclusions your Finance Committee would respectfully submit that

"(1) The voting machine is a simple, reliable, durable and convenient apparatus for its purpose.
} 
"(2) The machine compels the deposit of a perfect and accurate ballot, of the form chosen by the voter.

"(3) It restricts the voter absolutely to the limits of the law and permits him freedom as absolute in voting within that limit.

" (4) Blank and defective ballots, the usual fault of ordinary methods of voting, are entirely done away with and no man loses his vote through defect of the system, or fault of his own, if he votes at all. The disfranchised voter becomes unknown.

"(5) Fraudulent voting is impossible as well as errors in voting.

"(6) The vote cast is registered, vote by vote, with absolute accuracy and certainty.

" (7) The result can be declared immediately upon the close of the polls, having been already completely counted.

" (8) The cost of the system is so much less than that of the old method that the machines usually pay for themselves in from three to seven years.

"The whole case may be summarized in a sentence: "The machines retain all the virtues and exclude all the vices of the old methods of balloting.' Their use would be entirely justified, even though they involve a more costly, rather than a much less expensive system. Their adoption is looked upon by your committee as promoting good politics, good morals and good finance."

The possible ultimate result of the general introduction of these new methods of election upon the freedom of the ballot and the honesty and accuracy of the count, and upon the future politics and economics of the state and nation, no one can probably quite realize or predict; but that this insurance of a full vote and an honest one will tell for good government, and the purification of parties and their methods, no one can doubt. As the representative of the Patent Office said, in his testimony before the Committee of Congress regarding the proposed, and later-enacted, measure legalizing the voting machine in federal elections we cannot doubt that "It is the last and best contribution to the science of good government."

Judge Cooley said that, in his opinion such a method is a 'constitutional right' of every voter. The most surprising fact is, perhaps, that in the case above referred to, there was but one protest, in the city of Ithaca, out of over 2500 voters. Every inspector of election signed a certificate to the effect that the experiment was absolutely satisfactory, and the only objections heard were from one 'party-leader,' and the only adverse interests discovered were those affected by the abolition of ballotprinting, which is a much larger item of cost-at political prices-than is usually supposed. Each printed ballot costs from four to twenty cents, at the various elections, municipal, state and general.

ITHACA, December, 1899.

\section{R. H. Thurston.}

\section{A COMPLETE MOSASAUR SKELETON, OSSE- OUS AND CARTILAGINOUS.*}

IN the spring of 1898, Professor S. W. Williston's fine memoir upon the Kansas Mosasaurs seemed to cover the subject completely, summing up all the facts derived from the great Kansas University collection, as well as many of the results of the labors of Cuvier, Owen, Marsh, Cope, Dollo, Baur, and others. But it appears impossible to say the last word in paleontology. Professor Williston himself has recently described a portion of the nuchal fringe of Platecarpus, as well as the epidermal fin contours. The remarkable specimen which has recently been mounted in the Marine Reptile Corridor of the American Museum throws new and welcome light not only upon Tylosaurus, but upon the anatomy of the Mosasaurs in general.

Together with the practically complete bony skeleton, are seen cartilages of the throat and chest, portions of the larynx, trachea, bronchi, the epicoracoids, as well as the suprascapulæ, the sternum and sternal ribs. Originally these parts were preserved entire, and we must deeply re-

* Extract from Memoirs of the American Museum of Natural History, Vol. I., Part IV. 